\title{
Investigating the Use of Jatropha Biodiesel in Compression Ignition Engines by Comparing Effects of Storage Time on Its Properties with the Standard Properties of Fossil-Diesel and Properties of Quality Biodiesel
}

\author{
Gershom Mwandila \\ Chemical Engineering Department, Copperbelt University, Kitwe, Zambia \\ Email: Gershom.Mwandila@cbu.ac.zm
}

Received June 3, 2012; revised July 8, 2012; accepted July 20, 2012

\begin{abstract}
Effects of storage time on some properties of Jatropha biodiesel were investigated over the storage time of 0 to 8 weeks at the temperature of $25^{\circ} \mathrm{C}$. Such properties as water content and density were found to increase at the rates of $5 \mathrm{ppm}$ and $14 \mathrm{~kg} / \mathrm{m}^{3}$ per week respectively. These rates translate into property values which compare closely with the standard properties of fossil-diesel and properties of quality biodiesel. As a result, the Jatropha biodiesel can be used as alternative fuel to fossil-diesel in compression ignition engines within 8 weeks of its production. However, the calorific value and flash point of the biodiesel decreased at the rate of $1.4^{\circ} \mathrm{C}$ and $2.5 \mathrm{MJ} / \mathrm{kg}$ per week respectively. Although the flash point was within the acceptable level for quality biodiesel, the calorific values were abnormally higher than the values for quality biodiesel of about $38.7 \mathrm{MJ} / \mathrm{kg}$. With the exception of the calorific values, the other properties were not reasonably affected.
\end{abstract}

Keywords: Properties; Fossil-Diesel; Quality Biodiesel; Standard Properties; Storage Time

\section{Introduction}

Fossil-diesel is a proven fuel for compression ignition engines. However, biodiesel can be used as an alternative fuel to fossil-diesel because of its advantages such as being a renewable resource, nontoxic, a clean burning, and a better lubricating fuel [1]. However, there is a great deal of concern about the effect of biodiesel on engines due to variations in its properties over storage time. There are concerns about reduced performance, damage to key components, or even engine failures that are blamed on rancid biodiesel [2]. Some manufacturers are wary about honouring their warrantees on engines if rancid biodiesel is used, while others are encouraging the use of biodiesel, generally [3]. Given the wide array of confusing reports, understanding the truth of the matter is not easy. As a result, it is important to investigate the effect of storage time on the quality of biodiesel by measuring its properties. The properties can be used to determine whether the biodiesel is rancid. These investigations can clear up much of the confusion about using biodiesel and can be used as a reliable guide to determine the freshness of biodiesel.

The water content of biodiesel is one of the properties that can be used to measure the quality of biodiesel. Water in biodiesel leads to formation of fatty acids and car- boxylic acids as the biodiesel gets hydrolysed [4]. The fatty acids are susceptible to polymerization and clumping which renders the fuel to atomise poorly, thereby leading to incomplete combustion and soot formation. Soot and free fatty acid may corrode metal parts in the fuel lines and engine [5]. The effect of water in biodiesel leads to increased density because of the presence of various acids. In addition, the presence of water promotes biological growth whose presence in biodiesel increases its density [6]. According to literature, the levels of water content in biodiesel should be less than or equal to $1500 \mathrm{ppm}$ for a quality biodiesel [7]. Any amount of water above this value will bottom out as free water which can be responsible for biological growth and the reverse reaction that turns biodiesel to fatty acids [6].

The other properties of biodiesel whose literature about their variation with storage time need to be sought are flash point and calorific values. These properties are expected to decrease with increase in storage time. Since the flash point of free carboxylic acids is generally in the range $38^{\circ} \mathrm{C}-66^{\circ} \mathrm{C}$, their presence in biodiesel would affect its flash point which normally is about $130^{\circ} \mathrm{C}$ [7]. On the other hand, biodiesel can decompose into fatty acids over some time and in the process reduce its calorific values 
[8]. Table 1 shows some comparisons of standard properties of fossil-diesel with properties of quality biodiesel [9].

The main objective of this research was to study the effect of storage time on some properties of quality biodiesel. In order to achieve the objective, biodiesel made from Jatropha seed oil was investigated by measuring some of its properties over the storage time stretching from 0 to 8 weeks.

\section{Method}

A sample of 5 litre Jatropha biodiesel was subjected to storage times of $0,1,3,6$ and 8 weeks. At the end of every one of these periods, some of its properties were measured as follows.

\subsection{Water Content}

The water content was determined by Karl Fischer (KF) Method. A KF reagent of volume $30 \mathrm{~cm}^{3}$ was placed in the titration vessel, cooled to the temperature of $-20^{\circ} \mathrm{C} \pm$ $0.5^{\circ} \mathrm{C}$ and titrated to dryness with iodine solution. Then a biodiesel sample measuring $5 \mathrm{~cm}^{3}$ was added and its water content titrated at the same temperature of $-20^{\circ} \mathrm{C} \pm$ $0.5^{\circ} \mathrm{C}[10]$.

\subsection{Density}

The density was measured as specific gravity by the density bottle method. The measurements were taken at the temperature of $25^{\circ} \mathrm{C} \pm 0.5^{\circ} \mathrm{C}$. Water was used as the reference substance and the density of the biodiesel was determined by using the density of water at $4^{\circ} \mathrm{C}$ but corrected to the density of biodiesel at the temperature of $25^{\circ} \mathrm{C} \pm$ $0.5^{\circ} \mathrm{C}[11]$.

\subsection{Flash Point}

The flash point of the biodiesel sample was determined by the Pensky-Martens tester using a closed vessel measurement technique. The thermometer incorporated with the tester was graduated to a maximum temperature of $200^{\circ} \mathrm{C}$ with an error of $\pm 0.5^{\circ} \mathrm{C}$. The heat supply was controlled such that the temperature rise on the thermometer was $5^{\circ} \mathrm{C} / \mathrm{min}-6^{\circ} \mathrm{C} / \mathrm{min}$ which ensured that the flash point was not missed [12].

Table 1. Comparison of standard properties of petro-diesel with properties of quality biodiesel.

\begin{tabular}{ccc}
\hline Property & Fossil-diesel & Biodiesel \\
\hline Water content $(\mathrm{ppm})$ & $<200$ & $<500$ \\
Density $\left(\mathrm{kg} / \mathrm{m}^{3}\right)$ & $820-880$ & $860-900$ \\
Flash point $\left({ }^{\circ} \mathrm{C}\right)$ & $<60$ & $<130$ \\
Low calorific value $(\mathrm{MJ} / \mathrm{kg})$ & 43 & 38.7 \\
\hline
\end{tabular}

\subsection{Calorific Value}

A sample of biodiesel weighing $1.4 \pm 0.001 \mathrm{~g}$ was placed on a sample disk which was rested on a wire loop holder. Then a $10 \pm 0.05 \mathrm{~cm}$ nichrome wire weighing $0.0288 \pm$ $0.001 \mathrm{~g}$ was placed into the sample and the whole assembly into a tightened bomb. The bomb was then pressurised with oxygen to the pressure of $20 \pm 0.5$ bar. A bath containing water of volume $1400 \pm 5 \mathrm{~cm}^{3}$ and a temperature sensor was stirred for $5 \pm 1$ minute to ensure the attainment of steady state before being used to record temperature. The change in the temperature of the bath was recorded every one minute to obtain the optimum temperature change for the determination of the calorific value [13].

\section{Results and Discussion}

The effect of the storage time on water content is shown in Figure 1.

Figure 1 shows that the water content of the sample increased with storage time at the rate of almost 5 ppm per week. In accordance with reference values in Table 1, it would take a long time for this biodiesel to be rancid. Besides, this biodiesel had water content within the acceptable levels.

The other property which has been investigated is the density. Figure 2 shows the effect of storage time on the density of the biodiesel.

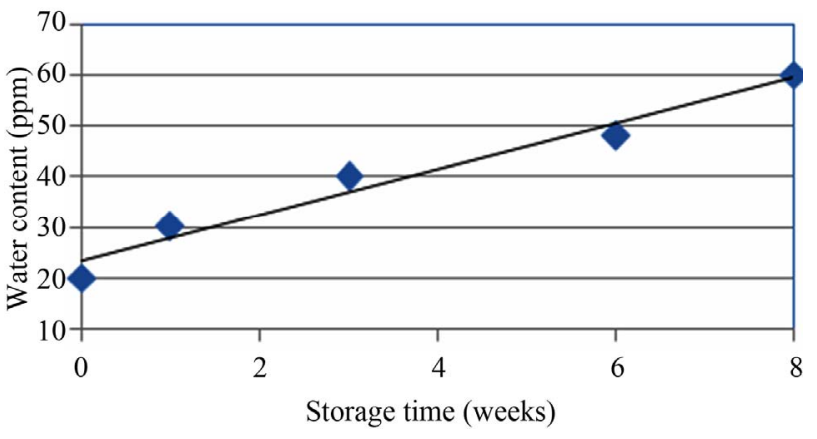

Figure 1. Effect of storage time on water content.

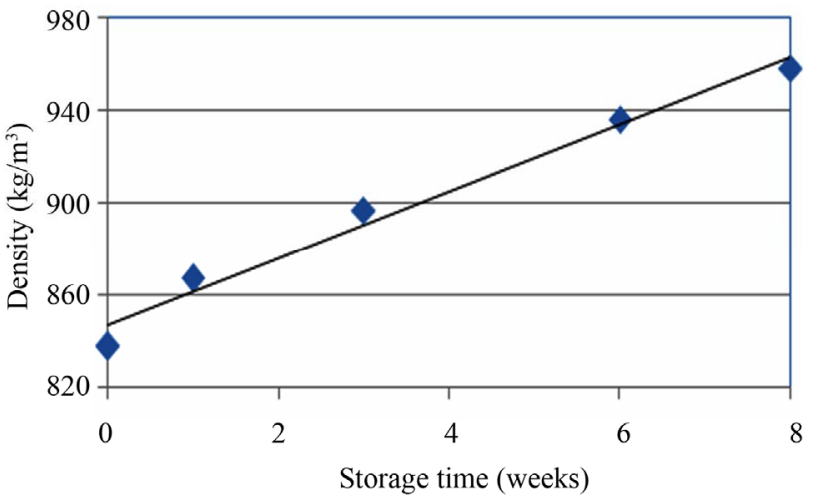

Figure 2. Effect of storage time on density. 
It can be seen in Table $\mathbf{1}$ and Figure $\mathbf{2}$ that the density of biodiesel compares well with that of fossil-diesel within three weeks of production. However, it increases gradually with storage time beyond that of fossil-diesel at the rate of $14 \mathrm{~kg} / \mathrm{m}^{3}$ per week. The effect of increased density is the reduction in the volume of the fuel which can be introduced into the combustion chamber and ultimately reduced consumption. On the other hand, reduced density may imply that the biodiesel is aging. Although by Figure 2 the density of biodiesel is reducing, it is still within the acceptable range for a quality biodiesel as can be compared with Table 1.

The results for the effect of storage time on the flash point of biodiesel are shown in Figure 3.

Figure 3 shows that the flash point of biodiesel is reducing with increase in storage time at the rate of $1.4^{\circ} \mathrm{C}$ per week. This result can be attributed to the increase in the water content which hydrolyses the biodiesel into fatty acids and carboxylic acids resulting in reduced flash points of the biodiesel. However, the flash point of the biodiesel is still less than the standard value of $130^{\circ} \mathrm{C}$. Since the results for the water content have shown that the biodiesel is not rancid, the decrease in flash point does not mean that the biodiesel is rancid.

The other property that was decreasing over some storage time was the calorific value. The effect of storage time on the calorific value of the biodiesel is shown in Figure 4.

It can be seen in Figure 4 that the calorific value of the biodiesel decreases with increasing storage time at the rate

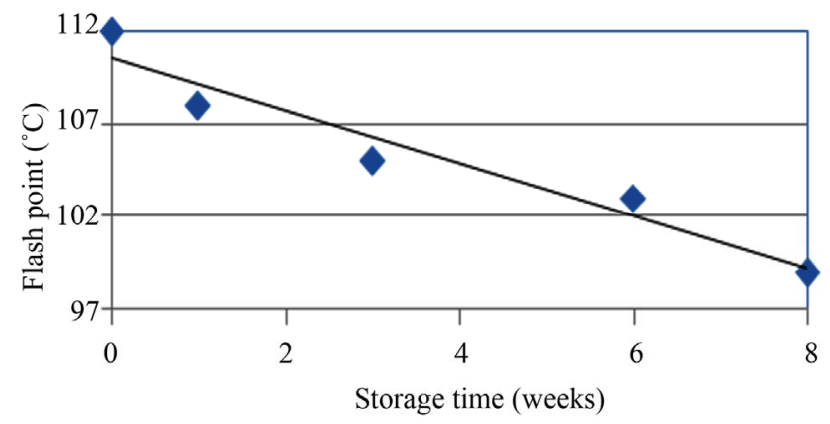

Figure 3. Effect of storage time on flash point.

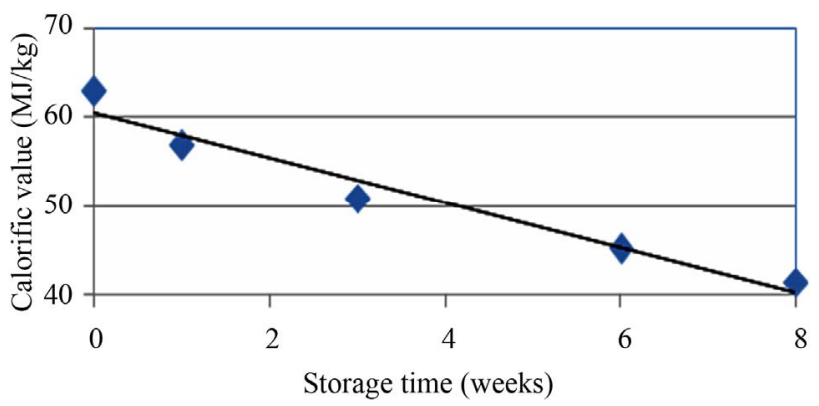

Figure 4. Effect of storage time on calorific value. of $2.5 \mathrm{MJ} / \mathrm{kg}$. In addition, the measured calorific values are much higher than of fossil-diesel which means that they were erroneously determined. According to literature, the calorific values of biodiesel are about $14 \%$ less than those of fossil-diesel [14]. The trend in Figure 4 is expected because calorific values of biodiesel decrease with increasing storage time. However, the calorific value of the biodiesel cannot be used to assess its freshness in this study because the values are not within acceptable range.

\section{Conclusion}

The suitability of the Jatropha biodiesel as an alternative fuel to fossil-diesel fuel was investigated by looking at the variations of its properties namely; water content, density and flash point over the storage time of 0 to 8 weeks at the temperature of $25^{\circ} \mathrm{C}$. It was found that the water content and density increased at the rates of $5 \mathrm{ppm}$ per week and $14 \mathrm{~kg} / \mathrm{m}^{3}$ per week respectively, which translates into property values of quality biodiesel and standard properties of fossil-diesel. Therefore, the Jatropha biodiesel can be an alternative fuel to fossil-diesel within 8 weeks of its production. However, the calorific value and flash point of the biodiesel decreased at the rate of $1.4^{\circ} \mathrm{C}$ and $2.5 \mathrm{MJ} / \mathrm{kg}$ per week respectively over the same storage time and conditions. In this case, the flash point values are within the standard values. However, the calorific values are abnormally higher than the standard values which could have been due to some experimental errors.

\section{Acknowledgements}

The author would like to thank Copperbelt Energy Corporation PLC (Zambia) for providing the biodiesel and some equipment for analysis. In addition, thanks go to $\mathrm{Mr}$. Henry Lubinda for helping with the sample and data collection.

\section{REFERENCES}

[1] A. Demirbas, "Progress and Recent Trends in Biodiesel Fuels,” Energy Conversion and Management, Vol. 50, No. 1, 2008, pp. 14-34. doi:10.1016/j.enconman.2008.09.001

[2] M. A. Fazal, A. S. M. A. Haseeb and H. H. Masjuki, "Biodiesel Feasibility Study: An Evaluation of Material Capability; Performance; Emission and Engine Performance,” Renewable and Sustainable Energy Reviews, Vol. 15, No. 2, 2010, pp. 1314-1324. doi:10.1016/j.rser.2010.10.004

[3] M. S. Graboski and R. L. McCormik, "Combustion of Fat and Vegetable Oil Derived Fuels in Diesel Engines," Progress in Energy and Combustion Science, Vol. 24, No. 2, 1997, pp. 125-164. doi:10.1016/S0360-1285(97)00034-8

[4] M. Canakci, "A Pilot Plant to Produce Biodiesel from High Free Fatty Acid Feedstocks,” ASAE Annual Interna- 
tional Meeting, Sacramento, 30 July August 1, 2001, pp. 1-29.

[5] D. Y. C. Leung, B. C. P. Koo and Y. Guo, "Degradation of Biodiesel under Different Storage Conditions,” Bioresource Technology, Vol. 97, No. 2, 2005, pp. 250-256. doi:10.1016/j.biortech.2005.02.006

[6] M. B. Oliveira, F. R. Varanda and I. M. Marrucho, "Prediction of Water Solubility in Biodiesel with CPA Equation of State," Industrial and Engineering Chemistry Research, Vol. 47, No. 12, 2008, pp. 4278-4285. hdoi:10.1021/ie800018x

[7] S. Fernando, et al., "Effect of Incompletely Converted Soybean Oil on Biodiesel Quality,” Energy, Vol. 32, No. 5, 2006, pp. 844-851. doi:10.1016/j.energy.2006.06.019

[8] A. Demirbas, "Calculation of Higher Heating Values of Biomass Fuels,” Fuel, Vol. 76, No. 5, 1997, pp. 431-434. doi:10.1016/S0016-2361(97)85520-2

[9] I. M. Atadashi, M. K. Aroua and A. A. Aziz, "High Quality Biodiesel and Its Diesel Engine Application: A Review," Renewable and Sustainable Energy Reviews, Vol. 14, No. 7, 2010, pp. 1999-2008. doi:10.1016/j.rser.2010.03.020

[10] S. A. Margolis and M. Levenson, "Certification by the
Karl Fischer Method of the Water Content in SRM 2890, Water Saturated 1-Octanol, and the Analysis of Associated Interlaboratory Bias in the Measurement Process," Fresenius Journal of Analytical Chemistry, Vol. 367, No. 1, 2000 pp. 1-7. doi:10.1007/s002160051589

[11] H. G. Midgley, "A Quick Method of Determining the Density of Liquid Mixtures,” Acta Crystallographica, Vol. 4, No. 8, 1951, p. 565. doi:10.1107/S0365110X51001835

[12] H. J. Liaw and Y.Y. Chiu, "A General Model for Predicting the Flash Point of Miscible Mixtures," Journal of Hazardous Materials, Vol. 137, No. 1, 2006, pp. 38-46. doi:10.1016/j.jhazmat.2006.01.078

[13] M. E. Boucher, A. Chaala and C. Roy, "Bio-Oils Obtained by Vacuum Pyrolysis of Softwood Bark as a Liquid Fuel for Gas Turbines. Part I: Properties of Bio-Oil and Its Blends with Methanol and a Pyrolytic Aqueous Phase,” Biomass and Bioenergy, Vol. 99, No. 5, 2000, pp. 337-350. doi:10.1016/S0961-9534(00)00043-X

[14] H. Ramadhas, C. Muraleedharan and S. Jayaraj, "Performance and Emission Evaluation of a Diesel Engine Fuelled with Methyl Esters of Rubber Seed Oil,” Renewable Energy, Vol. 30, No. 12, 2005, pp. 1789-1800. doi:10.1016/j.renene.2005.01.009 